\title{
VfZ online
}

Auf unserer Homepage (www.ifz-muenchen.de/vierteljahrshefte/) finden Sie

- die Vorschau auf das kommende Heft (auch als ToC Alert abonnierbar),

- Informationen über das German Yearbook of Contemporary History,

- das Forum mit Diskussionsbeiträgen zu aktuellen Aufsätzen,

- die Dokumentationen (Video und Transkript) der Veranstaltungen im Rahmen des „Podiums Zeitgeschichte“,

- die Videokolumne „Rückblicke“ mit Re-Lektüren älterer Beiträge,

- Informationen zu den sehepunkten, der VfZ-Schreibschule etc.,

- das offene Heftarchiv der VfZ mit allen Ausgaben seit 1953 (Moving Wall: fünf Jahre) sowie den Zugang zum kostenpflichtigen elektronischen VfZ-Angebot beim Verlag DeGruyter Oldenbourg,

- Hinweise zu Abonnement und Einzelverkauf,

- Informationen zu Profil sowie Herausgebergremium und Redaktion und nicht zuletzt

- aktuelle Informationen zu den vielfältigen Themen rund um die VfZ.

\section{Merkblatt für Autorinnen und Autoren}

www.ifz-muenchen.de/vierteljahrshefte/autorenhinweise/

\section{Begutachtungsverfahren}

Die Vierteljahrshefte für Zeitgeschichte sind eine referierte Zeitschrift, deren Beiträge in der Regel ein dreistufiges Begutachtungsverfahren zur Qualitätssicherung durchlaufen: Nach einer Sichtung und Bewertung der anonymisierten Beiträge durch die Redaktion werden externe Gutachten im In- und Ausland eingeholt (Double Blind Peer Review). Dann entscheiden Herausgeber und Redaktion nach eingehender Diskussion über die Veröffentlichung.

The Vierteljahrshefte für Zeitgeschichte are a refereed journal. For quality control purposes, contributions as a rule run through a three step evaluation process: After review and assessment of the anonymised contributions by the editorial staff, external domestic and foreign expertises are obtained (Double Blind Peer Review). On this basis and after thorough debate, the chief editors and editorial staff then decide on publication. 


\section{DE}

\section{GERMAN YEARBOOK OF CONTEMPORARY HISTORY}

\section{VOLUME 3}

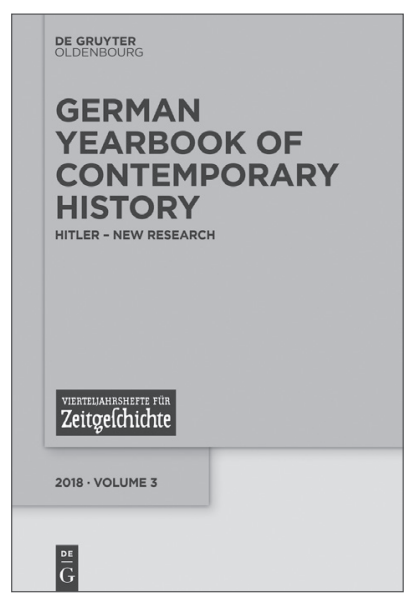

Elizabeth Harvey, Johannes Hürter (Eds.)

HITLER - NEW RESEARCH

2018. 244 pages

HC RRP € 49.95 [D]/US\$ 57.99/£ 45.50

ISBN 978-3-11-055322-2

eBook RRP $€ 49.95$ [D]/US\$57.99/£ 45.50

PDF ISBN 978-3-11-055560-8

ePUB ISBN 978-3-11-055346-8

How should we understand Hitler as a factor in the history of the Third Reich? Academic interest in the German dictator has been increasing once again, as shown by recent debates surrounding the publication of "Mein Kampf," and by numerous new studies on Hitler's personality, ideology and politics. Edited by Elizabeth Harvey (University of Nottingham) and Johannes Hürter (Institute of Contemporary History Munich - Berlin), the third volume of the German Yearbook of Contemporary History presents the latest in German research on Hitler based on selected articles from the Vierteljahrshefte für Zeitgeschichte. Novel theories concerning Hitler's personality and authenticity, the sources of his radical racism, and the relationship between the dictator and German society are assessed by renowned experts from the English-speaking world. 